\title{
Treatment of Complicated Henoch-Schönlein Purpura with Mycophenolate Mofetil: A Retrospective Case Series Report
}

\author{
A. A. Nikibakhsh, H. Mahmoodzadeh, M. Karamyyar, S. Hejazi, M. Noroozi, A. A. Macooie, \\ A. Gholizadeh, and L. Gholizadeh \\ Department of Pediatric Nephrology, Urmia University School of Medicine, Iran
}

Correspondence should be addressed to A. A. Nikibakhsh, anikibakhsh@yahoo.com

Received 27 December 2009; Revised 28 March 2010; Accepted 30 April 2010

Academic Editor: Malcolm Smith

Copyright (C) 2010 A. A. Nikibakhsh et al. This is an open access article distributed under the Creative Commons Attribution License, which permits unrestricted use, distribution, and reproduction in any medium, provided the original work is properly cited.

Background. Henoch-Schönlein purpura (HSP) is the most common childhood vasculitis with an incidence of approximately 10 per 100000 children. There is some evidence to support steroid therapy in the treatment of severe abdominal pain, severe nephritis, and central nervous system involvement. However, the routine use of corticosteroids is controversial. Frequent relapses, lack of response to steroid, steroid dependency, and steroid side effects may occur in some patients. Mycophenolate mofetil (MMF) gains increasing popularity in the treatment of autoimmune disorders, but hitherto, the available evidence to support the use of MMF in HSP is limited to some case study reports. Case Presentation. We report six children with HSP who failed to respond to systemic steroid therapy, whereas MMF successfully treated the manifestations of the disease. Conclusion. The manifestations of HSP disappeared mainly during the first week of treatment with MMF and all the patients were in a complete remission at the end and after discontinuation of the therapy. In our experience, MMF appeared to be safe and effective for the maintenance of remission in the HSP patients.

\section{Introduction}

Henoch-Schönlein purpura (HSP) is the most common vasculitis in children with an incidence of approximately 10 per 100,000 children per year and is slightly common among boys $(60 \%)$ than girls $(40 \%)$ [1]. The diagnosis is based on the palpable purpura in the presence of one of either diffuse abdominal pain, a biopsy showing predominant immunoglobulin A (IgA) deposition, arthritis, or arthralgia and/or renal involvement (hematuria and/or proteinuria) [2]. Typically, patient is a young child presenting with clinical manifestations including palpable purpura, arthritis, abdominal pain and gastrointestinal bleeding. The etiology of HSP is mainly unknown and antecedent upper respiratory tract infection, usually viral, has been reported and Streptococcal infection has been emphasized as an important triggering factor [3]. Also it is known that IgA plays an important role in the pathogenesis of the disease [1]. Most cases are self-limiting and require no treatment apart from symptomatic relief, but recurrence of symptoms occurs in about $33 \%$ of the cases. It seems that relapse often occurs between two weeks and 18 months after initial resolution of symptoms and children with kidney involvement are more likely to have recurrences [4]. In some patients, nephritis occurs due to IgA deposition in the renal mesangium [1]. More serious complications such as the involvement of central nervous system, renal failure, and intussusception may also occur. There is no consensus on the optimal treatment in the case of significant renal or other organs involvement where treatment may have a significant impact on the long-term outcome.

The routine use of corticosteroids in HSP is controversial. In a randomized placebo controlled study of oral prednisolone, abdominal symptoms were more prolonged in the prednisolone group. Further, there was no significant difference in the development of gastrointestinal complications the exception was the development of two intussusceptions in the placebo group and none in the steroid group [5]. 
On the contrary, some retrospective studies and case reports have suggested a benefit of steroids such as prednisolone in the treatment of abdominal pain [6, 7], HSP nephritis, and as prophylaxis for nephropathy $[8,9]$. Then, the treatment of HSP nephritis remains controversial [4]. HSP nephritis accounts for $1.8-3 \%$ of children with chronic kidney disease [10] and the presence of nephrotic/nephritic syndrome has been associated with a poor prognosis [4]. Long-term renal impairment occurs in $19.5 \%$ of those with a history of nephritic or nephrotic syndrome [11] which may imply a necessity for a more aggressive treatment to improve the outcome.

Mycophenolate mofetil (MMF), an immunosuppressive agent, has been widely used in the organ transplantation including pediatric renal transplantation [12]. MMF also appears to be a promising therapeutic agent in many autoimmune diseases such as lupus nephritis and in IgA nephropathy which is a form of primary glomerulonephritis [13]. Hitherto, the available evidence to support the use of MMF in HSP is limited to some case study reports [14].

In this case series study, we report the benefit effect of MMF in the treatment of some complicated HSP cases. The study subjects include six patients admitted into pediatric nephrology ward in a public hospital in Urmia-Iran. The patients were admitted with the diagnosis of HSP from March 2007 through March 2008. All the patients had been administrated steroid initially to control their complications including severe abdominal pain, gastrointestinal bleeding, and severe nephritis. Subsequently, medication changed to MMF regarding the following criteria (1) unresponsive to steroid, (2) steroid side effects, and (3) steroid dependency (two times of relapse during steroid tapering).

\section{Case Series}

2.1. Case Number 1: A 6-year-old boy referred to our hospital with the exacerbation of HSP symptoms including typical diffuse palpable purpuric and hemorrhagic lesions, abdominal pain, and arthritis. The patient had moon face, body weight gain, relapse of gastrointestinal bleeding, and severe abdominal pain despite taking prednisolone for eight weeks $(2 \mathrm{mg} / \mathrm{kg} /$ day for the first four weeks and $2 \mathrm{mg} / \mathrm{kg} /$ every other day for the last four weeks). Abdominal sonography was normal. Antistreptolysin-O (ASO) titer was 250 Todd, C reactive protein (CRP) was qualitatively positive $(+2)$, erythrocyte sedimentation rate $($ ESR) was $55 \mathrm{~mm} / \mathrm{h}$, and Antineutrophil cytoplasmic antibody (ANCA) as well as antinuclear antibodies (ANAs) yielded negative results. We tapered off the prednisolone gradually and switched to MMF $30 \mathrm{mg} / \mathrm{kg} /$ day. The gastrointestinal bleeding stopped during the first 48 hours of treatment and all symptoms and cutaneous manifestations resolved during the first week. The treatment continued for the next three weeks. There was no evidence of relapse in a 6-month follow-up.

2.2. Case Number 2: A 21-month-old boy presented with typical diffuse palpable purpuric and hemorrhagic lesions, hematuria, gastrointestinal bleeding, abdominal pain, and
TABLE 1: Demographic features of patients.

\begin{tabular}{|c|c|c|c|}
\hline & AGE & Sex & $\begin{array}{l}\text { Presenting signs and } \\
\text { symptoms }\end{array}$ \\
\hline Case 1 & $6 \mathrm{yr}$ & Male & $\begin{array}{l}\text { Palpable purpura, } \\
\text { Hemorrhagic purpura, } \\
\text { Arthritis, Abdominal pain }\end{array}$ \\
\hline Case 2 & 21 month & Male & $\begin{array}{l}\text { Palpable purpura, } \\
\text { Hemorrhagic purpura, } \\
\text { Arthralgia, Abdominal } \\
\text { pain, Hematuria, } \\
\text { Gastrointestinal bleeding }\end{array}$ \\
\hline Case 3 & $2 \mathrm{yr}$ & Male & $\begin{array}{l}\text { Palpable purpura, } \\
\text { Hemorrhagic purpura, } \\
\text { Elbow and ankle arthritis, } \\
\text { Abdominal pain, } \\
\text { Hematuria, } \\
\text { Gastrointestinal bleeding }\end{array}$ \\
\hline Case 4 & $6 \mathrm{yr}$ & Male & $\begin{array}{l}\text { Palpable purpura, } \\
\text { Gastrointestinal bleeding, } \\
\text { Abdominal pain, Arthralgia }\end{array}$ \\
\hline Case 5 & $7 \mathrm{yr}$ & Female & $\begin{array}{l}\text { Proteinuria, Hematuria, } \\
\text { Palpable purpura, } \\
\text { Hemorrhagic purpura, } \\
\text { Arthritis, Abdominal pain, } \\
\text { Gastrointestinal bleeding, } \\
\text { Generalized edema }\end{array}$ \\
\hline Case 6 & 18 month & Male & $\begin{array}{l}\text { Diffuse purpuric lesions, } \\
\text { Gastrointestinal bleeding, } \\
\text { Severe abdominal pain, } \\
\text { Microscopic hematuria }\end{array}$ \\
\hline
\end{tabular}

arthralgia. Abdominal CT scan and sonography were normal. ASO titer was 166 Todd, CRP was +1, and ESR was $61 \mathrm{~mm} / \mathrm{h}$. Despite treatment with prednisolone for two months $(2 \mathrm{mg} / \mathrm{kg} /$ day for the first month and $2 \mathrm{mg} / \mathrm{kg} /$ every other day for the second month), there was no lasting improvement in HSP symptoms (abdominal pain, arthralgia, purpuric and hemorrhagic lesions). Gastrointestinal bleeding was exacerbated and two episodes of relapse observed. He had moon face and body weight gain. Steroid therapy changed to MMF $30 \mathrm{mg} / \mathrm{kg} /$ day. Abdominal pain and gastrointestinal bleeding resolved in one week. Treatment with MMF was continued for the next two weeks and then tapered off in the next month. There was no evidence of relapse in a 6-month follow-up.

2.3. Case Number 3: A 2-year-old boy presented with typical diffuse palpable purpuric and hemorrhagic lesions, ankle and elbow arthritis, hematuria, gastrointestinal bleeding, and abdominal pain. Abnormal laboratory tests were CRP = +3 , ESR $=42 \mathrm{~mm} / \mathrm{h}$. Abdominal sonography and other laboratory tests were normal. The patient was under steroid therapy for eight weeks $(2 \mathrm{mg} / \mathrm{kg} /$ day $)$ and he had moon face and body weight gain. With tapering steroid, exacerbation and recurrence occurred for three times (steroid dependency). MMF $30 \mathrm{mg} / \mathrm{kg} /$ day was administered and tapering of steroid commenced and discontinued after three weeks. All the clinical manifestations resolved in one month of 
TABLE 2: Laboratory data and ultrasonographic findings of patients. * Only qualitative measurement of CRP was available at our center.

\begin{tabular}{|c|c|c|c|c|c|c|c|c|c|c|c|c|}
\hline & $\begin{array}{l}\mathrm{WBC} / \\
\mathrm{mm}^{3}\end{array}$ & $\begin{array}{c}\text { Hemoglobin } \\
\text { gr/dL }\end{array}$ & $\begin{array}{l}\text { Platelet/ } \\
\mathrm{mm}^{3}\end{array}$ & $\mathrm{CRP}^{*}$ & $\begin{array}{c}\text { ESR1st } \\
\mathrm{hr}\end{array}$ & $\mathrm{PT} / \mathrm{PTT}$ & ANCA & $\begin{array}{c}\text { ASO (normal } \\
<125 \mathrm{U}) \\
\text { Todd unit }\end{array}$ & $\begin{array}{l}\mathrm{BUN} \\
\mathrm{mg} / \mathrm{dL}\end{array}$ & $\begin{array}{l}\text { Creatinine } \\
\mathrm{mg} / \mathrm{dL}\end{array}$ & Urinalysis & $\begin{array}{c}\text { Abdominal } \\
\text { ultrasonography }\end{array}$ \\
\hline Case 1 & 8500 & 12.1 & 253000 & ++ & 55 & Normal & Neg. & 250 & 12 & 0.6 & Normal & Normal \\
\hline Case 2 & 7600 & 11.6 & 374000 & + & 61 & Normal & Neg. & 166 & 10 & 0.5 & Many RBC & Normal \\
\hline Case 3 & 10500 & 11.8 & 320000 & +++ & 42 & Normal & Neg. & Neg. & 11 & 0.7 & Many RBC & Normal \\
\hline Case 4 & 9400 & 12.2 & 288000 & + & 29 & Normal & Neg. & 333 & 14 & 0.5 & Normal & Normal \\
\hline Case 5 & 11700 & 12.4 & 425000 & +++ & 74 & Normal & Neg. & Neg. & 12 & 0.6 & $\begin{array}{c}\text { Protein: } \\
++++ \\
\text { Many RBC }\end{array}$ & Normal \\
\hline Case 6 & 7800 & 11.6 & 301000 & Neg. & 18 & Normal & Neg. & Neg. & 13 & 0.5 & Normal & Normal \\
\hline
\end{tabular}

the treatment and MMF was tapered during the next month. There was no evidence of relapse over one-year follow-up.

2.4. Case Number 4: A 6-year-old boy was referred to our hospital with HSP symptoms exacerbation. The patient had palpable purpura, gastrointestinal bleeding, abdominal pain, and arthralgia in spite of taking prednisolone $(2 \mathrm{mg} / \mathrm{kg} /$ day $)$ for weeks. Abnormal laboratory tests were ASO $=333$ Todd, CRP $=+1$, ESR $=29 \mathrm{~mm} / \mathrm{h}$. Abdominal sonography and other laboratory tests were normal. We administered MMF $30 \mathrm{mg} / \mathrm{kg} /$ day while tapering steroid therapy gradually. Treatment with MMF continued for one month and tapered off within the next month. There was no evidence of recurrence over one-year follow-up.

2.5. Case Number 5: A 7-year-old girl referred to our hospital due to developing nephrotic level of proteinuria (above $2 \mathrm{gr} /$ day) and microscopic hematuria following steroid tapering. Before admission to our hospital, the patient had diffuse palpable purpuric and hemorrhagic lesions, arthritis, generalize edema, microscopic hematuria, gastrointestinal bleeding, and severe abdominal pain. At the beginning of the disease, Methylprednisolone pulse (20 mg/kg/day) had been started intravenously for three times (every other day) and continued with oral prednisolone $2 \mathrm{mg} / \mathrm{kg}$ /day for the first month and $2 \mathrm{mg} / \mathrm{kg} /$ every other day for the second month.

Abnormal laboratory findings were $\mathrm{CRP}=+3, \mathrm{ESR}=$ $74 \mathrm{~mm} / \mathrm{h}$ see Table 2 . Other laboratory tests including serum lipids, serum albumin, ASO, ANCA, ANA, C3, C4, BUN, and Scr were normal. Due to continuing significant proteinuria (above $2 \mathrm{gr} /$ day) and microscopic hematuria, renal biopsy was performed and showed diffuse mesangial cell proliferation (light microscope) and predominant deposition of IgA in mesangial matrix and basement membrane of glomerulus (immunofluorescence microscope). After admission of the patient to our hospital, treatment with MMF $30 \mathrm{mg} / \mathrm{kg} /$ day commenced and the oral prednisolone $(2 \mathrm{mg} / \mathrm{kg} /$ every other day) which had been started since 2 months ago was discontinued.

After treatment with MMF for two months, proteinuria diminished from $2 \mathrm{gr} /$ day to $130 \mathrm{mg} /$ day, but microscopic hematuria continued. After six months, MMF was discontinued and after a six-month follow-up there was not any clinical and laboratory abnormality except mild microscopic hematuria.

2.6. Case Number 6: An 18-month-old boy referred to us due to steroid dependency and frequent recurrences while taping steroid. The patient presented with diffuse purpuric lesions, gastrointestinal bleeding, severe abdominal pain, and microscopic hematuria in spite of taking prednisolone ( $2 \mathrm{mg} / \mathrm{kg} /$ day for four weeks and $2 \mathrm{mg} / \mathrm{kg} /$ every other day for six weeks). The patient was readmitted again to hospital with gastrointestinal bleeding and arthritis for fourth times. Abdominal sonography and laboratory tests including ESR, CRP, and ASO were normal. After admission of the patient to our hospital, MMF $30 \mathrm{mg} / \mathrm{kg} /$ day commenced and steroid was tapered off gradually. All clinical manifestations resolved within one week and hematuria improved after one month of the treatment with MMF. Treatment with MMF was tapered off during the next month. There was no evidence of recurrence over one-year follow-up.

\section{Discussion}

MMF gains increasing popularity in the treatment of autoimmune disorders such as lupus nephritis, vasculitis, necrotizing glomerulonephritis, corticosteroid resistant glomerulonephritis, and $\operatorname{IgA}$ nephropathy $[12,13,15]$. It has been shown that MMF suppresses lymphocyte proliferation and decreases antibody production in the kidney diseases [13]. Recent studies suggest that mycophenolatic acid (MPA), the active metabolite of MMF, can significantly inhibit the adhesion of leukocytes to endothelial cells, which is a key process in the development of ANCA-associated vasculitis [16]. Hu et al. found that MMF was effective in controlling disease activity and improving renal function in Chinese patients with MPO-ANCA-associated vasculitis [16]. In another report, a patient with adult crescentic progressive glomerulonephritis in whom long-term complete remission was achieved after MMF therapy was discussed by Dede [13]. A case of HSP that manifested after pantoprazole ingestion has been reported recently by Muzaffar [17]. In this patient, the clinical manifestations including terminal ileitis and rapidly progressive glomerulonephritis were initially unresponsive to intravenous pulse steroids, whereas, his 
TABLE 3: Treatment protocols and outcomes of patients.

\begin{tabular}{|c|c|c|c|c|c|c|}
\hline & $\begin{array}{l}\text { Corticostroid } \\
\text { Dose/Route/Duration }\end{array}$ & $\begin{array}{l}\text { Response to } \\
\text { corticostroid }\end{array}$ & $\begin{array}{l}\text { Mycophenolate } \\
\text { mofetil (MMF) } \\
\text { Dose/Duration }\end{array}$ & $\begin{array}{l}\text { Response to } \\
\text { Mycophenolate } \\
\text { mofetil (MMF) }\end{array}$ & $\begin{array}{l}\text { Mean arterial } \\
\text { pressure (mmHg) } \\
\text { before treatment } \\
\text { by Mycophenolate } \\
\text { mofetil (MMF) }\end{array}$ & $\begin{array}{l}\text { Mean arterial } \\
\text { pressure }(\mathrm{mmHg}) \\
\text { one week after } \\
\text { treatment by } \\
\text { Mycophenolate } \\
\text { mofetil (MMF) }\end{array}$ \\
\hline Case 1 & $\begin{array}{l}\text { Prednisolone } 2 \mathrm{mg} / \mathrm{kg} / \mathrm{d} \\
\text { PO for } 8 \text { weeks }\end{array}$ & $\begin{array}{l}\text { Stroid } \\
\text { dependency }\end{array}$ & $\begin{array}{l}30 \mathrm{mg} / \mathrm{kg} \text { For } 3 \\
\text { weeks }\end{array}$ & $\begin{array}{l}\text { Significant } \\
\text { recovery in } 48 \\
\text { hours }\end{array}$ & 84 & 86 \\
\hline Case 2 & $\begin{array}{l}\text { Prednisolone } 2 \mathrm{mg} / \mathrm{kg} / \mathrm{d} \\
\text { PO for } 8 \text { weeks }\end{array}$ & $\begin{array}{l}\text { Stroid } \\
\text { dependency }\end{array}$ & $\begin{array}{l}30 \mathrm{mg} / \mathrm{kg} \text { For } 6 \\
\text { weeks }\end{array}$ & $\begin{array}{l}\text { Significant } \\
\text { recovery in one } \\
\text { week }\end{array}$ & 78 & 77 \\
\hline Case 3 & $\begin{array}{l}\text { Prednisolone } 2 \mathrm{mg} / \mathrm{kg} / \mathrm{d} \\
\text { PO for } 8 \text { weeks }\end{array}$ & $\begin{array}{l}\text { Stroid } \\
\text { dependency }\end{array}$ & $\begin{array}{l}30 \mathrm{mg} / \mathrm{kg} \text { For } 8 \\
\text { weeks }\end{array}$ & $\begin{array}{l}\text { Significant } \\
\text { recovery in one } \\
\text { month }\end{array}$ & 80 & 80 \\
\hline Case 4 & $\begin{array}{l}\text { Prednisolone } 2 \mathrm{mg} / \mathrm{kg} / \mathrm{d} \\
\text { PO for } 2 \text { weeks }\end{array}$ & No response & $\begin{array}{l}30 \mathrm{mg} / \mathrm{kg} \text { For } 8 \\
\text { weeks }\end{array}$ & $\begin{array}{l}\text { Significant } \\
\text { recovery in one } \\
\text { month }\end{array}$ & 86 & 85 \\
\hline Case 5 & $\begin{array}{l}\text { Methyl prednisolone } \\
20 \mathrm{mg} / \mathrm{kg} \text { IV for } 3 \text { doses } \\
\text { every other day then } \\
\text { Prednisolone } 2 \mathrm{mg} / \mathrm{kg} / \mathrm{d} \\
\text { for first } 4 \text { weeks and } \\
2 \mathrm{mg} / \mathrm{kg} / \text { every other day } \\
\text { for second } 4 \text { weeks }\end{array}$ & No response & $\begin{array}{l}30 \mathrm{mg} / \mathrm{kg} \text { For } 6 \\
\text { month }\end{array}$ & $\begin{array}{l}\text { Significant } \\
\text { recovery of } \\
\text { proteinuria but } \\
\text { continuation of } \\
\text { microscopic } \\
\text { hematuria }\end{array}$ & 86 & 90 \\
\hline Case 6 & $\begin{array}{l}\text { Prednisolone } 2 \mathrm{mg} / \mathrm{kg} / \mathrm{d} \\
\text { PO for first } 4 \text { weeks and } \\
2 \mathrm{mg} / \mathrm{kg} / \text { every other day } \\
\text { for second } 4 \text { weeks }\end{array}$ & $\begin{array}{l}\text { Stroid } \\
\text { dependency }\end{array}$ & $\begin{array}{l}30 \mathrm{mg} / \mathrm{kg} \text { For } 8 \\
\text { weeks }\end{array}$ & $\begin{array}{l}\text { Significant } \\
\text { recovery in one } \\
\text { month }\end{array}$ & 76 & 79 \\
\hline
\end{tabular}

renal function recovered after treatment with MMF [17]. In a study, the clinical courses of six patients (four boys and two girls with mean age of 13.2 years) with HSP and nephrotic syndrome were reviewed [18]. In this study, the treatment protocols included oral prednisolone, and in the nonresponders included cyclosporine A, cyclophosphamide, MMF, or tacrolimus see Table 3. They suggested that an early aggressive immunosuppressive approach improves long-term renal outcome in HSP patients with nephrotic syndrome [18].

Filler et al. described the pharmacokinetics of MMF in 15 pediatric patients with vasculitis and connective tissue diseases involving the kidney. Therapy was effective in inducing remission in four of nine patients with active diseases. Relapse occurred in only one of five other patients. All of six patients with controlled disease maintained remission. There were few side effects including diarrhea and leukocytopenia in one case and viral infections in two cases. They conclude that $\mathrm{MMF}$ at $900 \mathrm{mg} / \mathrm{m}^{2}$ per day appears to be effective in these patients [19].

In our case series study, we report six cases with HSP in whom steroid therapy failed to treat complications and keep in persistent remission so, medication switched to MMF (Table 1). All patients were closely followed up at least for six months for any complaint, symptoms, and signs of HSP such as palpable purpura, and arthritis. Blood pressure, serum creatinine level, complete blood count, platelet count, hematocrit, urine analysis, urine protein measurement, and side effects of MMF have been checked in the patients. In our study, MMF was found to be a useful immunosuppressant due to its fewer undesirable effects and good treatment effects for control of complication and relapse of HSP.

There was not any significant side effect, except mild anemia in the case 2 (not required any intervention) and mild diarrhea in the case 3 which relived by changing MFM to four divided doses. HSP manifestations disappeared mainly during the first week of treatment with MMF. With the exception of one patient with persistent hematuria for a long time, all the patients achieved complete remission at the end and after discontinuation of the therapy.

In our experience, MMF appeared to be effective for maintenance of remission in HSP patients.

There is some evidence to support steroid therapy in the treatment of severe abdominal pain, gastrointestinal bleeding, severe nephritis, and central nervous system involvement [20]. However, as seen in our patients, frequent relapses, lack of response to steroid, steroid dependency, and steroid side effects have been reported $[14,15]$. In literature the other treatment choices in complicated and sever HSP patients varied from combined heavy immunosuppressant (Cyclosporine, Cyclophosphmide) therapy to plasmapheresis [21]. So, we considered a more specific alternative to steroid therapy for HSP patients. 
On the other hand, considering favorable experiences with MMF such as less adverse effects than other immunosuppressive drugs, benefit effects in the treatment of many immunologically mediated renal diseases, and the antifibrotic and antiproliferative effects of it [22,23], it is suggested that MMF can be especially valuable in the treatment of the complicated HSP.

According to this case series study, MMF can be a safe and effective medication in the treatment of the complicated HSP. So, therapy could be changed to MMF considering the following criteria: unresponsive to steroid, steroid side effects, and steroid dependency (two relapses during steroid tapering). However, there are some important factors that may influence the results of our study including the possibility of spontaneous improvement of HSP without intervention, therapeutic effects of antecedent steroid before starting MMF. It is important to point out that we do not claim MMF works in all patients and some patients with HSP may fail MMF and may require more aggressive treatment.

So, more controlled prospective studies are necessary to prove the efficacy of this medication in the HSP treatment.

\section{Conclusion}

The results of this case series study suggest that mycophenolate mofetil would be a promising therapeutic alternative in the treatment of the complicated HSP. However, multicentre clinical trials with long-term followup will be necessary to confirm effectiveness of MMF in the treatment of the complicated HSP patients.

\section{References}

[1] F. T. Saulsbury, "Epidemiology of Henoch-Schönlein purpura," Cleveland Clinic Journal of Medicine, vol. 69, no. 2, pp. 87-89, 2002.

[2] S. Ozen, N. Ruperto, M. J. Dillon, et al., "EULAR/PReS endorsed consensus criteria for the classification of childhood vasculitides," Annals of the Rheumatic Diseases, vol. 65, no. 7, pp. 936-941, 2006.

[3] Y. K. Abdel-Al, Z. Hejazi, and H. A. Majeed, "HenochSchönlein purpura in Arab children. Analysis of 52 cases," Tropical and Geographical Medicine, vol. 42, no. 1, pp. 52-57, 1990.

[4] E. J. Tizard and M. J. J. Hamilton-Ayres, "Henoch-Schönlein purpura," Archives of Disease in Childhood, vol. 93, no. 1, pp. $1-8,2008$.

[5] A. M. Huber, J. King, P. McLaine, T. Klassen, and M. Pothos, "A randomized, placebo-controlled trial of prednisone in early Henoch Schönlein Purpura," BMC Medicine, vol. 2, article 7, 2004.

[6] M. Haroon, "Should children with Henoch-Schönlein purpura and abdominal pain be treated with steroids?" Archives of Disease in Childhood, vol. 90, no. 11, pp. 1196-1198, 2005.

[7] J. Ronkainen, O. Koskimies, M. Ala-Houhala, et al., "Early prednisone therapy in Henoch-Schönlein purpura: a randomized, double-blind, placebo-controlled trial," Journal of Pediatrics, vol. 149, no. 2, pp. 241-247, 2006.

[8] Y. Kaku, K. Nohara, and S. Honda, "Renal involvement in Henoch-Schönlein purpura: a multivariate analysis of prognostic factors," Kidney International, vol. 53, no. 6, pp. 1755-1759, 1998.
[9] F. Mollica, S. Li Volti, R. Garozzo, and G. Russo, "Effectiveness of early prednisone treatment in preventing the development of nephropathy in anaphylactoid purpura," European Journal of Pediatrics, vol. 151, no. 2, pp. 140-144, 1992.

[10] P. Niaudet and R. Habib, "Methylprednisolone pulse therapy in the treatment of severe forms of Schonlein-Henoch purpura nephritis," Pediatric Nephrology, vol. 12, no. 3, pp. 238-243, 1998.

[11] H. Narchi, "Risk of long term renal impairment and duration of follow up recommended for Henoch-Schönlein purpura with normal or minimal urinary findings: a systematic review," Archives of Disease in Childhood, vol. 90, no. 9, pp. 916-920, 2005.

[12] M. R. Benfield, J. M. Symons, S. Bynon, et al., "Mycophenolate mofetil in pediatric renal transplantation," Pediatric Transplantation, vol. 3, no. 1, pp. 33-37, 1999.

[13] F. Dede, B. Onec, D. Ayli, I. I. Gonul, and K. Onec, "Mycophenolate mofetil treatment of crescentic HenochSchönlein nephritis with IgA depositions," Scandinavian Journal of Urology and Nephrology, vol. 42, no. 2, pp. 178-180, 2008.

[14] S. Martin, C. H. Cramer, J. Heikenen, and J. J. Gitomer, "Gastrointestinal symptoms of Henoch-Schönlein purpura treated with mycophenolate mofetil," Journal of Pediatric Gastroenterology and Nutrition, vol. 43, no. 2, pp. 245-247, 2006.

[15] S. Mendizábal, I. Zamora, O. Berbel, M. J. Sanahuja, J. Fuentes, and J. Simon, "Mycophenolate mofetil in steroid/ cyclosporine-dependent/resistant nephrotic syndrome," Pediatric Nephrology, vol. 20, no. 7, pp. 914-919, 2005.

[16] W. Hu, C. Liu, H. Xie, H. Chen, Z. Liu, and L. Li, "Mycophenolate mofetil versus cyclophosphamide for inducing remission of ANCA vasculitis with moderate renal involvement," Nephrology Dialysis Transplantation, vol. 23, no. 4, pp. 13071312, 2008.

[17] M. Muzaffar, A. Taj, and N. Sethi, "Kaw rapidly progressing glomerulonephritis secondary to Henoch-Schönlein purpura treated with mycophenolate mofetil: a case report with atypical etiology and presentation," to appear in American Journal of Therapeutics.

[18] R. F. Andersen, S. Rubak, B. Jespersen, and S. Rittig, "Early high-dose immunosuppression in Henoch-Schönlein nephrotic syndrome may improve outcome," Scandinavian Journal of Urology and Nephrology, vol. 43, no. 5, pp. 409-415, 2009.

[19] G. Filler, M. Hansen, C. LeBlanc, et al., "Pharmacokinetics of mycophenolate mofetil for autoimmune disease in children," Pediatric Nephrology, vol. 18, no. 5, pp. 445-449, 2003.

[20] P. F. Weiss, J. A. Feinstein, X. Luan, J. M. Burnham, and C. Feudtner, "Effects of corticosteroid on Henoch-Schönlein purpura: a systematic review," Pediatrics, vol. 120, no. 5, pp. 1079-1087, 2007.

[21] R. Bogdanović, "Henoch-Schönlein purpura nephritis in children: risk factors, prevention and treatment," Acta Paediatrica, vol. 98, no. 12, pp. 1882-1889, 2009.

[22] H. W. Sollinger, "Mycophenolates in transplantation," Clinical Transplantation, vol. 18, no. 5, pp. 485-492, 2004.

[23] P. M. Stassen, C. G. M. Kallenberg, and C. A. Stegeman, "Use of mycophenolic acid in non-transplant renal diseases," Nephrology Dialysis Transplantation, vol. 22, no. 4, pp. 10131019, 2007. 


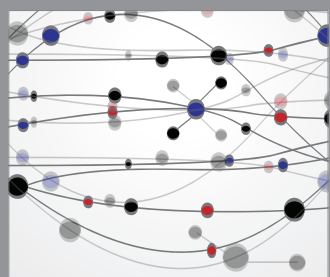

The Scientific World Journal
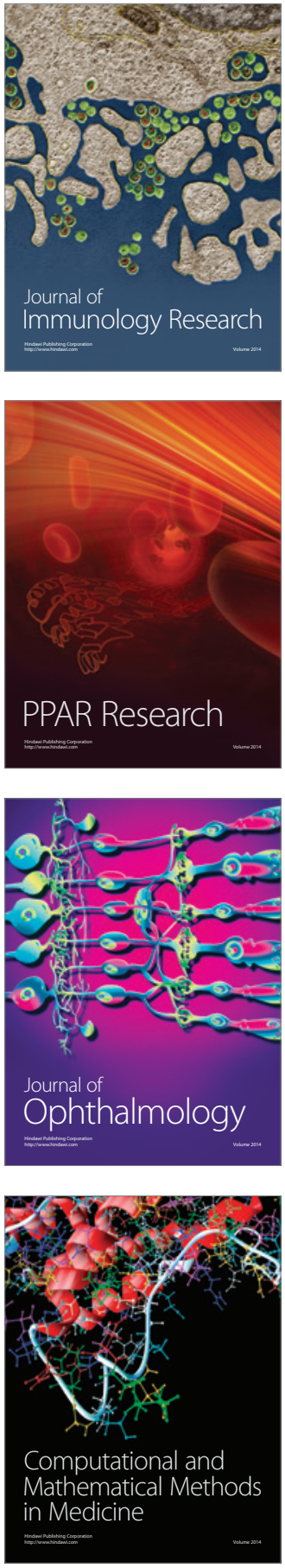

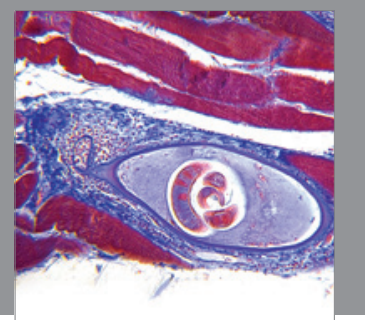

Gastroenterology

Research and Practice
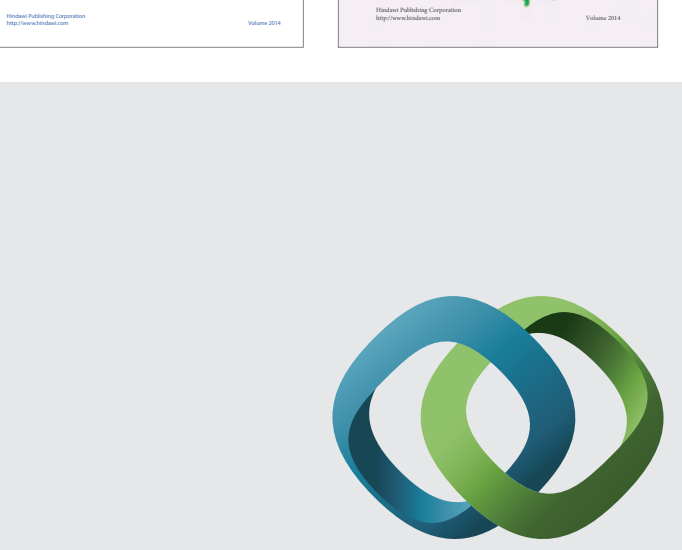

\section{Hindawi}

Submit your manuscripts at

http://www.hindawi.com
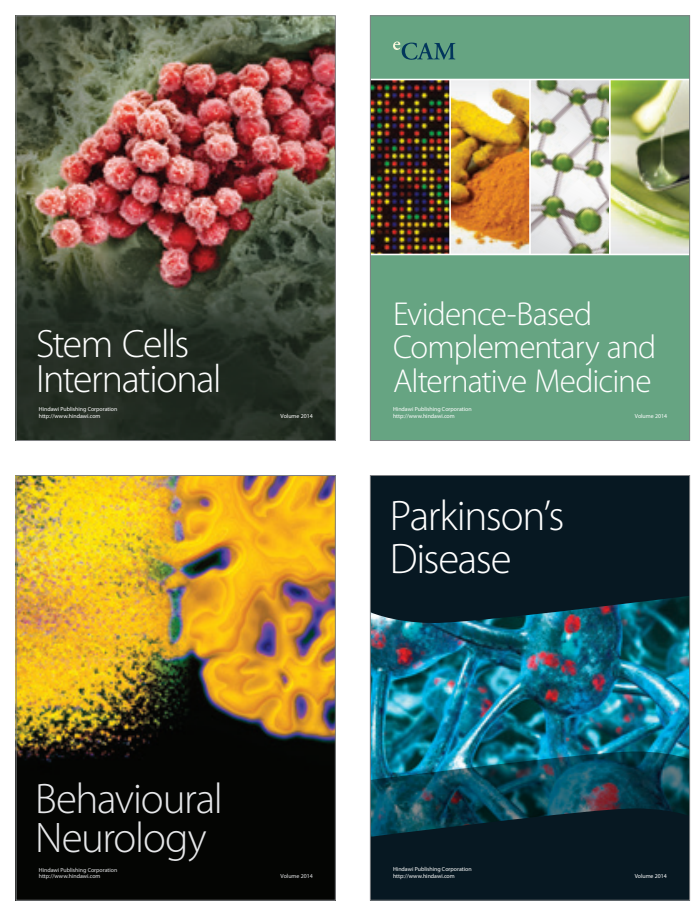

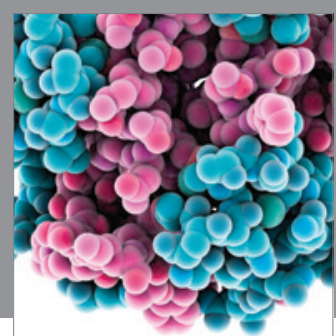

Journal of
Diabetes Research

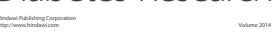

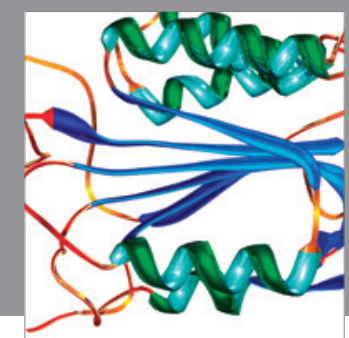

Disease Markers
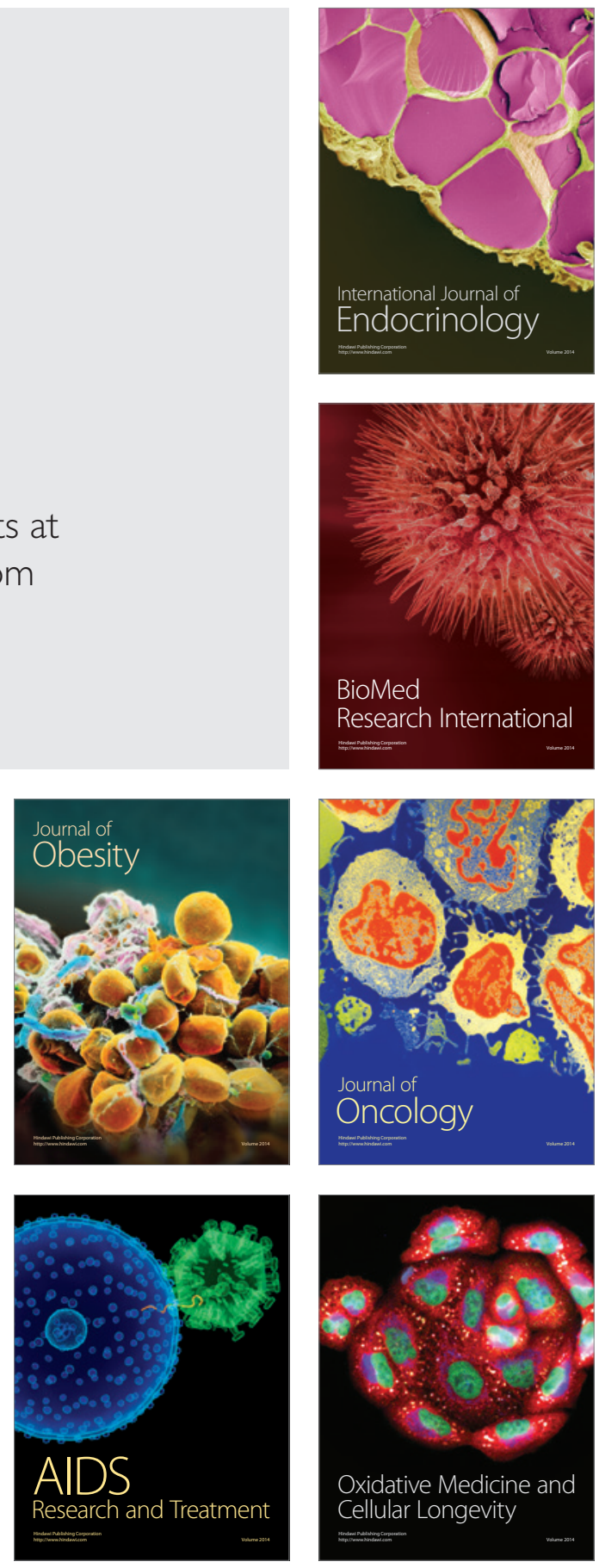